УДК 351.84

DOI https://doi.org/10.32849/2663-5313/2020.6.21

Оксана Брусакова,

канд. філос. наук, дочент,

декан факультету № 6

Харківського начіонального університету внутрішніх справ

\title{
ПОНЯТТЯ ТА СУТНІСТЬ МЕХАНІЗМУ ДЕРЖАВНОГО РЕГУЛЮВАННЯ В ГАЛУЗІ АВІАЦЙНОГО ТРАНСПОРТУ
}

У статті аргументовано, що авіаиійна галузь є сьогодні прибутковим сектором економіки, спрямована здебільшого на задоволення приватних інтересів фізичних або юридичних осіб. У зв'язку з иим постає питання визначення мети та завдань впливу держави на авіачійну галузь, тобто яким чином та в яких межах держава в особі уповноважених органів здійснює державне регулювання цієї галузі. Виокремлено елементи механізму державного регулювання авіачійної галузі, а саме: 1) інституиійна складова; 2) функціональна складова (мета, завдання та правовідносини); 3 ) інструментальна складова, яка представлена правовим інструментарієм (форми і методи). Надано характеристику видів механізму державного регулювання авіаційної галузі, таких як: 1) міжнародно-правовий механізм державного регулювання авіаційної галузі; 2) конституиійно-правовий механізм державного регулювання авіаційної галузі; 3) фінансово-правовий механізм державного регулювання авіачійної галузі; 4) кримінально-правовий механізм державного регулювання авіачійної галузі; 5) адміністративноправовий механізм державного регулювання авіаційної галузі. Зроблено висновок, шо під механізмом державного регулювання в галузі авіачійного транспорту запропоновано розуміти нормативно визначену сукупність взаємоузгоджених і взаємозалежних компонентів, які забезпечують ефективне функиіонування авіачійної галузі шляхом запровадження авіачійних правил для того, щоб можливо було задовольнити приватні та публічні інтереси, зберегти баланс останніх та надати можливість зацікавленим суб'єктам повночінно реалізовувати закріплені в Конституиї України права, свободи та законні інтереси. При иьому інструментальною складовою иього механізму виступають адміністративно-правові засоби зобов'язального характеру, які трансформуються в авіачійні правила. Саме вдале використання адміністративно-правових засобів надає можливість упорядкувати різні за правовою природою авіачійні відносини, які об'єднані спільною метою, шо полягає в реалізаиї конституиійних прав, свобод і законних інтересів, підтриманні балансу публічних і приватних інтересі та забезпеченні авіачійної безпеки тощо.

Ключові слова: авіаційна галузь, авіаційний транспорт, авіаційна діяльність, механізм державного управління, інституційна складова, функціональна складова, інструментальна складова.

Постановка проблеми. Сучасний світ настільки став інтегрований, що не може існувати без технічних засобів, які спрощують цей процес. Транспорт сьогодні - це головна артерія, яка дозволяє задовольнити різні потреби людини та з'єднати всі куточки світу між собою. Тобто транспорт є тим елементом, який дозволяє вирішити питання переміщення людей і товарів як всередині окремої держави, так і між державами. 3 огляду на потреби та спосіб життя сучасної людини, вона не може обійтися без авіаційного транспорту, який, особливо після підписання Україною У годи про інтеграцію до ЄС, став невід'ємною частиною інтеграційного процесу, за допомогою якої відбувається переміщення людей між країнами. Наголосимо, що авіаційна галузь є нині прибутковим сектором економіки і спрямована здебільшого на задоволення приватних інтересів фізичних або юридичних осіб. Тому постає питання визначення мети та завдань впливу держави на авіаційну галузь, тобто яким чином та в яких межах держава в особі уповноважених органів здійснює державне регулювання цієї галузі.

Аналіз останніх досліджень і публікацій. Для розв'язання поставленої проблеми звернемося до наукових напрацювань відомих вчених-адміністративістів, які займалися питаннями державного регулювання транспортної сфери в цілому та авіаційної зокрема. Це В. Б. Авер'янов, О. М. Бандурка, Ю. П. Битяк, Я. Й. Баган, Т. О Гуржій, В. Л. Грохольський, В. К. Гіжвський, Н. В. Дараганова, О. В. Джафарова, Е.Ф.Демський, Р. А. Калюжний, І. Я. Козачок, Т. О. Коломоєць, А. Т. Комзюк, 
О. В. Кузьменко, В. К. Мілашевич, М. М. Новікова, С. М. Радзівон, В. Й. Разводовський, А. В. Сєчко, А. О. Собакарь, В. Ю. Степанов, В. М. Столбовий, О. Г. Хороманська, А. В. Філіппов та інші. Праці вищезгаданих дослідників будуть для нас основою для визначення поняття та сутності механізму державного регулювання в галузі авіаційного транспорту.

Виклад основного матеріалу. Зауважимо, що державне регулювання авіаційної галузі $є$ нині найбільш оптимальною формою впливу держави на суспільні відносини шляхом встановлення загальнообов'язкових авіаційних правил поведінки для всіх учасників 3 метою задоволення публічних та приватних інтересів у цій сфері. Як правило, «державне регулювання» - це статична категорія, яка практично реалізується через певний «механізм». Категорія «механізм» має технічне забарвлення, оскільки ототожнюється із певною сукупністю деталей та складників, які дають можливість привести в дію певний об’єкт. На цьому наголошує Ю. О. Світлична, зазначаючи, що категорія «механізм» здебільшого характеризує технічні конструкції й пов'язується із певним рухом та роботою певних агрегатів [1, с. 133-134].

При цьому Великий тлумачний словник сучасної української мови надає таке визначення: це «внутрішня будова, устрій, система функціонування чого-небудь, апарат будь-якого виду діяльності» [2, с. 523]. Д. С. Норт під механізмом пропонує розуміти знаряддя, пристосування для упорядкування чого-небудь, сукупність станів та процесів, з яких складається будь-яке явище [3, с. 88]. Наголосимо, що ця категорія знаходить своє застосування і в інших сфеpax життєдіяльності людини, це пов'язано 3 тим, що вона є науковою абстракцією, яка надає можливість охарактеризувати значне коло явищ і процесів із досягнення певного результату. Серед вчених-правознавців існує думка, що під категорією «механізм» слід розуміти сукупність методів, форм, прийомів, способів, завдяки правильному використанню яких можливо буде досягти оптимальної організації всіх елементів системи, їх ефективного функціонування, що в результаті повинно привести до отримання бажаного результату [4, с. 37-38]. Загалом підтримуючи вищенаведену позицію, вважаємо іiі завузькою, оскільки вона не враховує всього складу необхідних базових елементів, завдяки правильному використанню яких можливо буде досягти оптимальної організації всіх елементів системи, їх ефективного функціонування, що в результаті повинно привести до отримання бажаного результату.
Зробимо проміжний висновок, який полягає в тому, що «механізм» як правова конструкція - це складне явище, яке має певний елементний склад, що надає можливість перетворитись певному явищу із наукової абстракції в площину правозастосування. При цьому зазначене явище має ряд характерних ознак, серед яких слід виокремити такі: 1) є динамічним явищем, яке постійне функціонує, а тому має рушійну силу; 2) складається з певної сукупності компонентів, які мають усталений характер; 3) рушійна сила спрямована на досягнення певного запланованого результату; 4) всі елементи взаємоузгодженні і взаємозалежні; 5) рушійна сила представлена сукупністю нормативно-правових актів, які визначають системність, узгодженість та надають можливість для цілеспрямованої роботи цього явища. Саме виходячи із цих характеристик спробуємо визначити, в чому полягає сутність механізму державного регулювання в цілому та галузі авіаційного транспорту зокрема. Тобто що саме виступає рушійною силою функції державного регулювання? Для цього проаналізуємо наявні наукові позиції з цього приводу з метою формулювання обгрунтованої авторської позиції. Відразу наведемо позицію Ю. О. Тихомирова, який робить висновок, що державне регулювання «прив'язується» лише до економіки й виступає одним із проявів або функцією державного управління в широкому розумінні. Воно характеризується як установлення та забезпечення державою загальних правил поведінки (діяльності) суб'єктів суспільних відносин і коригування їх залежно від умов, що змінюються [5, с. 376]. Ми підтримуємо зазначену позицію, оскільки коли йдеться про «державне регулювання», то передбачається створення оптимального правового клімату (поля) для того, щоб можливо було задовольнити приватні та публічні інтереси, зберегти баланс останніх та надати можливість зацікавленим суб'єктам повноцінно реалізовувати закріплені в Конституції України права, свободи та законні інтереси. Як правило, такі відносини виникають, коли йдеться про господарську діяльність, метою якої є отримання прибутку.

У зв'язку з цим звернемо увагу на категорії, які визначають «механізм державного регулювання економіки». Дослідник С. Чистов розглядає механізм державного регулювання через систему знань про сутність, закономірності дії та правила застосування типових методів і засобів впливу держави на перебіг соціально-економічного розвитку, спрямованих на досягнення цілей державної економічної політики. При 
цьому вчений наголошує, що зазначену категорію також слід розглядати 3 практичного погляду, що включає сферу діяльності держави щодо цілеспрямованого впливу на поведінку суб'єктів господарювання з метою забезпечення пріоритетів державної економічної політики [6]. Загалом погоджуючись із цим визначенням, наголосимо, що визначати мету такого механізму тільки як забезпечення пріоритетів економічної політики, на нашу думку, є завузькою позицією. Деякі вчені визначають механізм державного регулювання економіки через функції (планування, програмування), окремі види економічної політики та правові засоби [7]. Такий підхід є не досить вдалим та не сприяє практиці правозастосування. У свою чергу О. М. Комяков, вважає, що механізм державного регулювання - це сукупність організаційно-економічних методів та інструментів, за допомогою яких виконуються взаємопов'язані функції для забезпечення безперервного, ефективного впливу відповідної системи (держави) на підвищення ефективності економіки [8]. Запропонований підхід не розкриває основне призначення зазначеного явища, яке полягає у створенні відповідного правового поля за допомогою якого визначається певний правовий інструментарій та відповідне коло публічних інституцій, злагоджена робота яких дає можливість виконати поставлену мету та завдання такого регулювання певної сфери суспільних відносин. Заслуговуе на увагу позиція Т. А. Піхняк, який пропонує розуміти під механізмом державного регулювання економіки спосіб організації економічних відносин між державою та підприємствами, населенням, іншими країнами та міжнародними інституціями з метою стабілізації соціально-економічної ситуації в країні та створення передумов для економічного зростання. Для забезпечення цих економічних відносин потрібні суб'єкт (виходячи з цього визначення, це держава) та об'єкт (щонайменше це підприємства, населення, інші країни та міжнародні інституції). Об'єктами державного регулювання економіки також можуть бути регіони, галузі та сектори економіки [9]. Запропоноване визначення найбільш повно розкриває зміст категорії, однак поза увагою дослідника залишились саме правові засоби, за допомогою яких і здійснюється упорядкування відносин у певній сфері економіки щодо підтримання балансу публічних та приватних інтересів. У науковій літературі визначення поняття саме «механізму державного регулювання авіаційної сфери» відсутнє. Тому спробуємо сформулювати власну авторську позицію з цього приводу з урахуванням сутності базової категорії.

Отже, під механізмом державного регулювання в галузі авіаційного транспорту будемо розуміти нормативно визначену сукупність взаємоузгоджених і взаємозалежних компонентів, які забезпечують ефективне функціонування авіаційної галузі шляхом запровадження авіаційних правил для того, щоб можливо було задовольнити приватні та публічні інтереси, зберегти баланс останніх та надати можливість зацікавленим суб'єктам повноцінно реалізовувати закріплені в Конституції України права, свободи та законні інтереси.

Для визначення особливостей механізму державного регулювання в галузі авіаційного транспорту доцільно звернутись до наукових напрацювань, які стосуються визначення переліку компонентів (елементів), які є базовими та визначають його зміст.

Слід не погодитись із позицією А. Л. Калімбета, який зазначає, що кожен механізм має свої специфічні підходи, функціональність у діяльності та набір елементів [10, с. 28]. Зауважимо, що перелік елементів механізму $є$ постійним, саме завдяки останнім і забезпечується стале функціонування певного явища. Змістове ж наповнення кожного базового елементу дійсно має свою специфіку. Так, наприклад, С. Серьогін та О. Петренко вважають, що «принципи», вихідні положення певного вчення, теорії; керівні ідеї, основні правила діяльності; основа організації, дії будь-якого механізму не придумані людьми довільно, а виведені на основі адекватного відображення природи, суспільства, мислення і є обов'язковим елементом механізму [11, с. 27-28]. Такої ж думки дотримується і О. Ф. Скакун, яка зазначає, що останній складається із принципів права, норм права, нетипових правових розпоряджень, правовідносин, суб'єктивних прав й обов'язків в їх індивідуалізації й актів застосування норм права [12, с. 498-499]. Про значення і цінність принципів як наукового явища писав С. П. Головатий у своєму дослідженні про зміст «принципу верховенства права», але, екстраполюючи останнє на предмет нашого дослідження, зауважимо, що принципи державного регулювання в цілому та в галузі авіації закріплені в нормативноправових актах вищої юридичної сили, тому виділення останніх як самостійного елемента механізму державного регулювання авіаційної галузі не має наукових підстав. У свою чергу А. Ф. Черданцев до елементів механізму відносить стадії процесу правового регулювання [13, с. 96-98]. Такої ж думки дотримуються і знані вчені С. С. Алексєєв 
та В. Н. Хропанюк, які виділяють три такі стадії: регламентування суспільних відносин, дія юридичних норм, реалізація суб'єктів прав і обов’язків [14, с. 341-342].

Висловлюючи власні міркування з цього приводу, наголосимо, що, коли йдеться про механізм правового регулювання, виділення таких елементів є обгрунтованим та логічним, оскільки визначається механізм реалізації окремої функції права, а саме регулюючої. У нашому випадку, аналізуючи саме механізм державного регулювання в цілому та в галузі авіації зокрема, виділення останніх вважаємо недоцільним, оскільки наша мета полягає у виділенні саме базових структурних елементів, які визначають спрямування регулюючої функції права на певні суспільні відносини. Так, О. Чечель механізм державного регулювання економіки розглядає як систему, яка становить компонентну структуру. Ïї складниками є цілі, завдання, принципи, функції, суб'єкти й об'єкти, методи та форми державного регулювання економіки, які у своїй взаємодії та взаємозв'язку зумовлюють економічну політику країни, реалізація якої сприятиме досягненню стратегічної мети та виконанню регулюючої функції держави у сфері державного управління [15].

Аналіз наукових напрацювань, які були нами наведені вище, дали нам можливість скласти власне уявлення про елементи механізму державного регулювання авіаційної галузі, а саме: 1) інституційна складова, яка представлена системою суб'єктів публічного та приватного права, що були спеціально створені державою для регулювання авіаційної галузі або їм були делеговані певні повноваження в цій сфері; 2) функціональна складова (мета, завдання та правовідносини); 3) інструментальна складова, що представлена правовим інструментарієм (форми і методи), який є необхідним для підтримання балансу публічних та приватних інтересів в авіаційній галузі та закріплений у нормативно-правових актах.

Наголосимо, що інструментальна складова механізму державного регулювання авіаційної галузі забезпечується за допомогою правового інструментарію, який має нормативне закріплення та містить, як правило, норми публічного права. При цьому приватноправовий механізм регулювання авіаційної галузі також має своє нормативне закріплення, але в цьому аспекті на перший план виходить задоволення приватного інтересу в галузі авіації, а саме отримання прибутку. Виходячи з цього, можна виділити такі види механізму державного регулювання авіаційної галузі, як:

- міжнародно-правовий механізм державного регулювання авіаційної галузі, який натепер є одним із ключових в упорядкуванні відносин в зазначеній сфері, оскільки саме за його допомогою урегульовано значне коло питань, пов'язаних із переміщенням осіб та товарів між різними державами. Як наголошувалось в наших попередніх публікаціях, вплив міжнародних організацій містить у собі риси опосередкованого державного регулювання. Як приклад наведемо проект наказу Державної авіаційної служби України «Про затвердження змін до Авіаційних правил України», представлений на офіційному сайті Державіаслужби і спрямований на зміни у «Правилах повітряних перевезень та обслуговування пасажирів і багажу» [16]. Зокрема, в проекті передбачені зміни у п. 1 глави 5 розділу XXVI Авіаційних правил України, запропоновані у зв'язку з отриманням листа IKAO від 11.10.2019 № LE3/38/1-19/70, у якому йдеться про перегляд лімітів відповідальності авіаперевізників, встановлених Монреальською конвенцією (збільшено на $13,9 \%)[17]$

- конституційно-правовий механізм державного регулювання авіаційної галузі містить посилання, які визначають базові засади нормативного регулювання зазначеної сфери. Серед таких норм - п. 5 ст. 92 Конституції України, де визначено, що засади використання природних ресурсів, виключної (морської) економічної зони, континентального шельфу, освоєння космічного простору, організації та експлуатації енергосистем, транспорту і зв'язку визначаються виключно законами України. Саме конституційно-правовий механізм визначає норми, які закріплюють права громадян на заняття підприємницькою діяльністю, на гарантування безпеки життя та здоров'я людини і громадянина та ряд інших. При цьому саме суб'єкти конституційно-правового механізму (Верховна Рада України, комітети Верховної Ради України) затверджують державну політику в галузі авіації та визначають вектор розвитку останньої;

- фінансово-правовий механізм державного регулювання авіаційної галузі також становить значну частину фінансових відносин у цій сфері, закріплений у фінансово-правових нормах та визначає питання, пов’язані із фінансово-господарською діяльністю, фінансовими витратами на забезпечення авіаційної безпеки; фінансового авіалізінгу, фінансового забезпечення розвитку авіаційної медицини тощо. Як приклад наведемо положення, що закріплено в Державній програмі авіаційної безпеки цивільної авіації, а саме: фінансування загальнодержавних видатків, пов'язаних із забезпеченням 
авіаційної безпеки, та інших витрат уповноваженого органу з питань цивільної авіації, пов'язаних із забезпеченням виконання його функцій з безпеки авіації, здійснюється за окремою бюджетною програмою на підставі та в межах річного кошторису з коштів, що надійшли до Державного спеціалізованого фонду фінансування загальнодержавних витрат на авіаційну діяльність та участь України у міжнародних авіаційних організаціях від справляння державного збору з авіаційної безпеки, у частині, що згідно із законодавством зараховується до спеціального фонду Державного бюджету України [18];

- кримінально-правовий механізм державного регулювання авіаційної галузі визначає коло кримінально-правових засобів, які застосовуються спеціально визначеними суб'єктами за завдання шкоди суспільним відносинам, які перебувають під охороною держави;

- адміністративно-правовий механізм державного регулювання авіаційної галузі охоплює найбільшу частину правовідносин у цій сфері, оскільки саме за його допомогою здійснюється упорядкування відносин та підтримання балансу публічних та приватних інтересів у сфері авіації за допомогою адміністративно-правових засобів.

\section{Висновок}

Отже, під адміністративно-правовим механізмом державного регулювання в галузі авіаційного транспорту будемо розуміти нормативно визначену сукупність взаємоузгоджених і взаємозалежних компонентів, які забезпечують ефективне функціонування авіаційної галузі шляхом запровадження авіаційних правил для того, щоб можливо було задовольнити приватні та публічні інтереси, зберегти баланс останніх та надати можливість зацікавленим суб'єктам повноцінно реалізовувати закріплені в Конституції України права, свободи та законні інтереси. При цьому інструментальною складовою цього механізму виступають адміністративно-правові засоби зобов'язального характеру, які трансформуються в авіаційні правила. Саме вдале використання адміністративно-правових засобів надає можливість упорядкувати різні за правовою природою авіаційні відносини, які об'єднані спільною метою, що полягає у реалізації конституційних прав, свобод і законних інтересів, підтриманні балансу публічних і приватних інтересів та забезпеченні авіаційної безпеки тощо.

Мета механізму правового регулювання подолання перепон на шляху задоволення інтересів суб'єктів права - досягається за допомогою використання сукупності засобів, які різняться за природою та функціональним призначенням, але об'єднані в систему спільною метою.

\section{Список використаних джерел:}

1. Світлична Ю.О. Адміністративно-правові засади державного регулювання іноземного інвестування в Україні : дис. ... доктора юрид. наук : 12.00.07. Харків, 2017. 433 с.

2. Великий тлумачний словник сучасної української мови / уклад. і голов. ред. В. Т. Бусел. Київ : Ірпінь: Перун, 2003. 1440 c.

3. Норт Д.С. Институты, институциональные изменения и функционирование экономики. Москва : Начала, 1997. 256 с.

4. Безпалова О. I. Адміністративно-правовий механізм реалізації правоохоронної функції держави : монографія. Харків : Харківський національний університет внутрішніх справ, 2014. $544 \mathrm{c}$.

5. Тихомиров Ю. А. Курс административного права и процесса. Москва : Юринформцентр, 1998. 798 c.

6. Чистов С. Державне регулювання економіки. Київ : КНЕУ, 2004. 446 с.

7. Макаренко П. М. Моделі аграрної економіки. Київ : ННЦ IAE, 2005. 682 с.

8. Комяков О. М. Державне регулювання перехідної економіки : автореф. дис. ... канд. екон. наук : 08.01.01. Київ, 2000. 19 с.

9. Піхняк Т. А. Проблеми механізму державного регулювання економічного зростання. Збірник наукових пращь Хмельницького кооперативного торговельно-економічного інституту. 2011. Вип. 1. URL: http://www.nbuv.gov.ua/ portal/soc_gum/Znphktei/2011_1/statti/pixnyak/ pixnyak.htm. (дата звернення: 15.05.2020).

10. Калімбет А.Л. Державне управління в галузі телебачення в Україні : дис. ... канд. юрид. наук : 12.00.07. Одеса, 2016. 207 с.

11. Серьогін С., Петренко О. Визначення принципів та сутності інтегрованого інституту публічної служби. Вісник Начіональної академії державного управління при Президентові України. Київ : Видавництво НАДУ, 2007. № 3. С. 25-35.

12. Скакун О. Ф. Теорія держави і права : підручник : пер. 3 рос. Харків : Консум, 2008. 656 c.

13. Черданцев А.Ф. Общая теория государства и права : учеб. для вузов. Москва : Юрайт, 2000. 432 с.

14. Хропанюк В. Н. Теория государства и права : учеб. пособие / под ред. проф. В. Г Стрекозова. Москва, 1995. 377 с.

15. Чечель О. Принципи та механізм державного регулювання економіки. Науковий вісник «Демократичне врядування». 2014. Вип. 13. URL: http://www.lvivacademy.com/vidavnitstvo_1/ visnik13/fail/Chechel.pdf (дата звернення: 15.05.2020)

16. Про затвердження Змін до Авіаційних правил України «Правила повітряних перевезень та обслуговування пасажирів і багажу» : проект 
наказу Державіаслужби. URL: https://avia.gov.ua/ wp-content/uploads/2020/02/nakaz-ta-zmini.pdf. (дата звернення: 18.05.2020).

17. Про затвердження Змін до Авіаційних правил України «Правила повітряних перевезень та обслуговування пасажирів і багажу» : порівняльна таблиця до проекту наказу Державіаслужби. URL: https://avia.gov.ua/wp-content/uploads/2020/02/ porivnyalna-tablitsya-1.pdf. (дата звернення: 18.05.2020)

18. Про Державну програму авіаційної безпеки цивільної авіації : Закон України від 21.03.2017 № 1965-VIII. URL : https://zakon.rada. gov.ua/go/1965-19. (дата звернення: 18.05.2020).

Oksana Brusakova. The concept and essence of the mechanism of state regulation in the field of air transport

It is argued that the aviation industry is today a profitable sector of the economy, aimed mainly at satisfying the private interests of individuals or legal entities. In this regard, the question arises of determining the goals and objectives of the state's impact on the aviation industry, that is, how and to what extent the state, through the authorized bodies, carries out state regulation of this industry. Elements of the mechanism of state regulation of the aviation industry are singled out, namely: 1) institutional component; 2) functional component (purpose, tasks and legal relations); 3) instrumental component, which is represented by legal tools (forms and methods). The characteristics of the types of the mechanism of the state regulation of the aviation branch are given as: 1) the international legal mechanism of the state regulation of the aviation branch; 2) the constitutional and legal mechanism of state regulation of the aviation industry;3) financial and legal mechanism of state regulation of the aviation industry; 4) criminal-legal mechanism of state regulation of the aviation industry; 5) administrative and legal mechanism of state regulation of the aviation industry. It is concluded that the mechanism of state regulation in the field of air transport is proposed to be understood as a normatively defined set of mutually agreed and interdependent components that together ensure the effective functioning of the aviation industry by introducing aviation rules to meet private and public interests. and to provide an opportunity for interested subjects to fully realize the rights, freedoms and legitimate interests enshrined in the Constitution of Ukraine. At the same time, the instrumental component of this mechanism is binding administrative and legal means, which are transformed into aviation rules. It is the successful use of administrative and legal means that makes it possible to regulate aviation relations of different legal nature, which are united by a common goal, which is to exercise constitutional rights, freedoms and legitimate interests, balance public and private interests and ensure aviation security.

Key words: aviation industry, aviation transport, aviation activity, public administration mechanism, institutional component, functional component, instrumental component. 